\title{
DISPERSION AND DIFFUSION ALONG COASTAL AREA OF NILE DELTA
}

\author{
Ebtessam El-Sayed El-Sayed Mohamed \\ Professor in physical Oceanography \\ Shore processor Laboratory \\ National Institute of Oceanography and Fisheries \\ Alexandria, Egypt
}

\begin{abstract}
A statistical analysis of drifter observations in 15 and 50m depth in front of Port Said and Rosetta is used to estimate the track of circulation pattern and the latitudinal and longitudinal velocity. A cyclonic motion covered the area from near surface to $50 \mathrm{~m}$ depth. The relative dispersion value was in the order of $10^{6} \mathrm{~cm}^{2} / \mathrm{sec}$.

The horizontal divergence is oscillating between conversion and diversion. Also the effect of turbulence is relatively small.
\end{abstract}

\section{INTRODUCTION}

The study of diffusion in sea water becomes an important issue due to the increase of discharge of various contaminants into the sea and its impact on the marine ecosystem. For that it is necessary to evaluate the horizontal eddy diffusivity and dispersion coefficient.

Many studies were carried out since 1950 to make direct estimation of the diffusivity in the ocean by various types of releasing experiments of dye or floats. Among these studies are that made by Ichiye (1962), Foxworthy at al.(1966), Okubo (1971) , Yanagi et al. (1982\& 1999), List et al.(1990), Yoshitaka Matsuzaki and Isamu Fujita, (2014); Yuqi Song (2017); Erik van Sebille et al (2018); L.M. Ivanov, P.C. Chu (2019); Victor Zhurbas (2014).

The study of oceanic diffusion treats the dispersion and diffusion process of various substances as contaminants from human civilization and physical components such as heat, salinity and momentum.

Two different methods can be used to estimate the magnitude of the horizontal diffusivity and dispersion coefficient. The first one is Eulerian method, using an array of fixed location recording current meters. The second method is Lagrangian description of flows depending on tracking groups of drifting floats.

The prediction of particle transport in the ocean has become possible due to the increased numerical accuracy and availability of numerical ocean analyses and re-analyses (Castanedo et al. 2006; Coppini et al 2010 and Michela De
Dominicis et al. 2012). It includes the effects of horizontal shear which is generated by average current and that of diffusion by turbulence (H. Aoyagi et al, 2004).

Nile Delta coast of Egypt lies in the south eastern Mediterranean. It is classified as one of the most vulnerable areas to climate change, as well as the most important part of the country from a socioeconomic viewpoint. The Nile Delta and its coastal zone contain a variety of development activities. It is a promising area for energy resources and industrial activities. The study of circulation pattern in the area appears the existence of gyres as El-Arish Gyre, which appear as a cyclonic in winter and anticyclonic in summer. (M.A. Said and F.M. Eid, 1994).

Many researchers carried out indirect studies of the current regime in the Eastern Mediterranean Their computations showed that the circulatory pattern was dominated by the inflow of less saline Atlantic water along the North African coast, and the existence of two gyres: Mersa Matruh anticyclonic gyre and the cyclonic Arish gyre (Sharaf El-Din and Karam, 1973, Morcos and Hasan, 1976, Abdel Moati and Said, 1987, Said and Karam, 1990; (Said and Eid, 1995)

The Lagrangian method was applied to study the characteristics of the surface current pattern in the eastern Mediterranean basin (Said et al., 2013). The satellite tracking of 81 free Lagrangian drifters deployed along the Egyptian continental slope confirmed the existence of Mersa Matruh and Ierapetra gyres, and the computed mean flow ranged from 0.2 to $0.25 \mathrm{~m} / \mathrm{s}$ directed eastwards.

El-Sharkawy et al (2013), there is a dominant westward surface flow existed during July 1999 with greater magnitudes compared to May 1999, as about 51\% ranged from 0.1 to $0.3 \mathrm{~m} / \mathrm{s}$, and $49 \%$ of the current ranged from 0.3 to $0.7 \mathrm{~m} / \mathrm{s}$. The average surface current was $0.25 \mathrm{~m} / \mathrm{s}$ toward $84^{\circ}$, and the maximum was $0.47 \mathrm{~m} / \mathrm{s}$. The bottom current was highly variable with about $55 \%$ of current ranging from 0.1 to $0.3 \mathrm{~m} / \mathrm{s}$, and $45 \%$ ranging from 0.3 to $0.7 \mathrm{~m} / \mathrm{s}$. The maximum bottom current was $0.47 \mathrm{~m} / \mathrm{s}$, while the average current was $0.25 \mathrm{~m} / \mathrm{s}$ heading toward $84^{\circ}$. 


\section{International Journal of Engineering Applied Sciences and Technology, 2019 \\ Vol. 4, Issue 7, ISSN No. 2455-2143, Pages 49-57 \\ Published Online November 2019 in IJEAST (http://www.ijeast.com)}

The aim of this study is to determine the water circulation in front of Nile Delta. Also determine the dispersive properties.

\section{DATA AND METHOD OF ANALYSIS}

Acting on behalf of the Belayim Petroleum Company, Fugro Global Environmental \& Ocean Sciences (Fugro GEOS) have undertaken a year-long programme of metocean measurements around the Offshore Nile Delta Field between May 1999 and May 2000. The aim of the survey was to collect current, wave, meteorological, water temperature and salinity data for modelling and design purposes.

The measurement programme was commissioned by Shell Egypt and extended a joint industry agreement between AMOCO, British Gas and I.E.O.C (International Egypt Oil Company).

During Nile Delta Metocean Survey, two pairs of drogue buoys equipped with Argos position and sea surface sensing systems were deployed. Each pair comprised systems to track currents at $15 \mathrm{~m}$ depth and $50 \mathrm{~m}$ depth. Deployment details are presented in the following table 1.

Table 1 The deployment details of the drogues.

\begin{tabular}{|c|c|c|c|c|c|}
\hline $\begin{array}{c}\text { DEPLOYM } \\
\text { ENT } \\
\text { LOCATIO } \\
\mathbf{N}\end{array}$ & $\begin{array}{l}\text { DEPT } \\
\text { H OF } \\
\text { DRO } \\
\text { GUE }\end{array}$ & $\begin{array}{c}\text { ARG } \\
\text { OS } \\
\text { ID NO }\end{array}$ & $\begin{array}{l}\text { DEPLOY } \\
\text { MENT } \\
\text { DATE/TI } \\
\text { ME GMT } \\
\text { STATION }\end{array}$ & $\begin{array}{c}\text { DATE } \\
\text { OF } \\
\text { LAST } \\
\text { TRANS } \\
\text { MI- } \\
\text { SSION }\end{array}$ & $\begin{array}{c}\text { COMME } \\
\text { NT }\end{array}$ \\
\hline $\begin{array}{l}32^{\circ} 36.462^{\prime} \mathrm{N} \\
30^{\circ} 13.830^{\prime} \mathrm{E}\end{array}$ & $15 \mathrm{~m}$ & 3744 & $\begin{array}{c}\text { 02-May-99 } \\
21: 02 \\
\text { near S4 }\end{array}$ & 13-Jul-99 & $\begin{array}{l}\text { Transmitted } \\
\text { after } \\
\text { programmed } \\
\text { stop. }\end{array}$ \\
\hline $\begin{array}{l}32^{\circ} 36.473^{\prime} \mathrm{N} \\
30^{\circ} 14.659^{\prime} \mathrm{E}\end{array}$ & $50 \mathrm{~m}$ & 15533 & $\begin{array}{c}\text { 02-May-99 } \\
\text { 20:48 } \\
\text { near S4 }\end{array}$ & 30-Jun-99 & $\begin{array}{l}\text { Programme } \\
\text { d stop. }\end{array}$ \\
\hline $\begin{array}{l}32^{\circ} 42.920^{\prime} \mathrm{N} \\
32^{\circ} 28.665^{\prime} \mathrm{E}\end{array}$ & $15 \mathrm{~m}$ & 1623 & $\begin{array}{c}\text { 04-May-99 } \\
23: 54 \\
\text { near S3 }\end{array}$ & $\begin{array}{l}\text { 19-May- } \\
99\end{array}$ & $\begin{array}{c}\text { Failed early, } \\
\text { cause } \\
\text { unknown. }\end{array}$ \\
\hline $\begin{array}{l}32^{\circ} 42.002^{\prime} \mathrm{N} \\
32^{\circ} 27.875^{\prime} \mathrm{E}\end{array}$ & $50 \mathrm{~m}$ & 3745 & $\begin{array}{c}\text { 04-May-99 } \\
23: 59 \\
\text { near S3 }\end{array}$ & 13-Jul-99 & $\begin{array}{l}\text { Transmitted } \\
\text { after } \\
\text { programmed } \\
\text { stop. }\end{array}$ \\
\hline
\end{tabular}

The positions of the four used drogues are represented in figure (1).

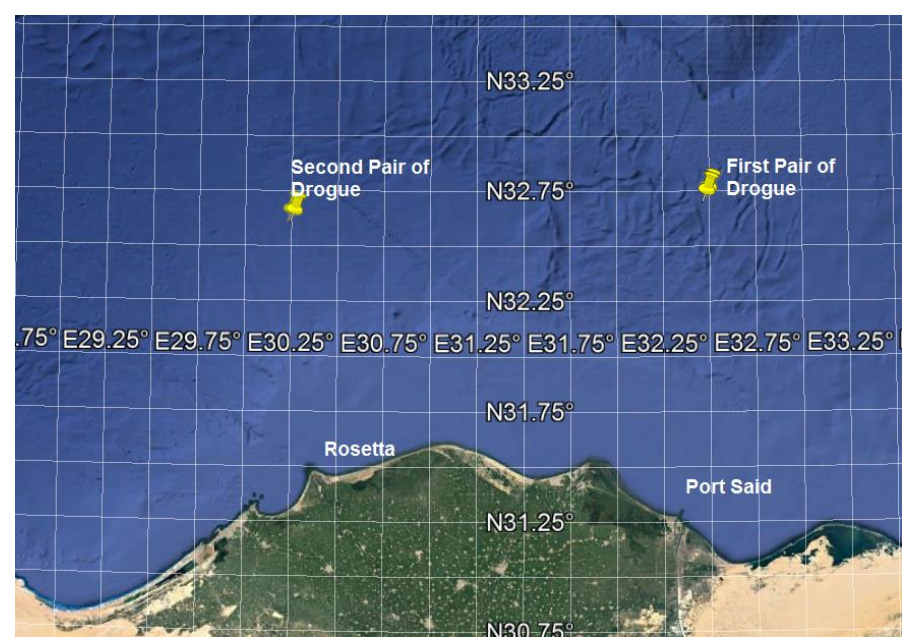

Figure (1) Location of drogues

\section{DISPERSION AND DIFFUSION}

The calculation of dispersion and diffusion coefficient is based on the work done by many authors. Let $(\mathrm{x}, \mathrm{y})$ is the location coordinate at time $\mathrm{t}$. Using the coordinates, the mean current speed can be evaluated on the basis of Lagrangian method as the time derivative of coordinate position.

The centroid position for certain interval of time can be calculated using the following equation.

$$
\begin{gathered}
X=\frac{\sum X i j}{N} \\
Y=\frac{\sum Y i j}{N}
\end{gathered}
$$

Where $\mathrm{N}$ is number of drifter measurements.

The variance of drogue position is calculated by the following equation $(3 \& 4)$

$$
\begin{aligned}
\sigma_{\mathrm{xi}} & =\frac{\sum_{j}(X i j-X) 2}{N-1} \\
\sigma_{\mathrm{yi}}^{2} & =\frac{\sum_{j}(y i j-Y) 2}{N-1}
\end{aligned}
$$

Then the dispersion of the drogue is calculated by the following equation:

$$
\sigma_{i}^{2}=\left(\sigma_{x i}^{2}+\sigma^{2}{ }_{y i}\right) / 2
$$

Then the relative dispersion coefficient $\mathrm{K}$ is calculated by the following equation:

$$
\mathrm{K}(\mathrm{ti})=1 / 2 \frac{d \sigma_{i}^{2}}{d t}
$$

And the spatial relative dispersion coefficient is calculated by the following equation:

$$
\begin{aligned}
& \mathrm{K}_{\mathrm{x}}\left(\mathrm{t}_{\mathrm{i}}\right)=1 / 2 \frac{d \sigma 2 \mathrm{xi}}{d t} \\
& \mathrm{~K}_{\mathrm{y}}\left(\mathrm{t}_{\mathrm{i}}\right)=1 / 2 \frac{d \sigma 2 \mathrm{yi}}{d t}
\end{aligned}
$$




\section{International Journal of Engineering Applied Sciences and Technology, 2019 Vol. 4, Issue 7, ISSN No. 2455-2143, Pages 49-57 \\ Published Online November 2019 in IJEAST (http://www.ijeast.com)}

\section{Horizontal divergence:}

It is calculated analytically from the data using the following equation:

Horizontal divergence $(\mathrm{Q})=\frac{\partial u}{\partial x}+\frac{\partial v}{\partial y}$

If $\mathrm{Q}$ is positive the motion is divergence

If $\mathrm{Q}$ is negative the motion is convergence

\section{Horizontal diffusivity:}

Using the location and speed of drogues $(\mathrm{x}(\mathrm{t}), \mathrm{y}(\mathrm{t})$ and $\mathrm{u}(\mathrm{t})$, $\mathrm{v}(\mathrm{t}))$, the relative velocity in $\mathrm{x}$ and $\mathrm{y}$ direction can be calculated from the following equation:

$$
\begin{gathered}
U^{*}{ }_{i}(t)=u_{i}(t)-\bar{u}(t) \\
V^{*}{ }_{i}(t)=v i(t)-\underline{u}(t)
\end{gathered}
$$

These equations can be extended by Taylor extension as:

$\mathrm{U}^{*}{ }_{\mathrm{i}}(\mathrm{t})=\mathrm{x}^{*}{ }_{\mathrm{i}}(\mathrm{t}) *(\partial \overline{\mathrm{u}} / \partial \mathrm{x})+\mathrm{y}^{*}{ }_{\mathrm{i}}(\mathrm{t}) *(\partial \overline{\mathrm{u}} / \partial \mathrm{y})+\mathrm{u}_{\mathrm{i}}{ }^{* *}(\mathrm{t})$

$\mathrm{V}^{*}{ }_{\mathrm{i}}(\mathrm{t})=\mathrm{x}_{\mathrm{i}}^{*}(\mathrm{t}) *(\partial \mathrm{v} / \partial \mathrm{x})+\mathrm{y}^{*}{ }_{\mathrm{i}}(\mathrm{t}) *\left(\partial{ }^{\prime} / \partial \mathrm{y}\right)+\mathrm{v}_{\mathrm{i}}{ }^{* *}(\mathrm{t})$

Where:

$$
\begin{aligned}
& X^{*}{ }_{i}(t)=X_{i}(t)-\ddot{X}(t) \\
& Y^{*}{ }_{i}(t)=Y_{i}(t)-\bar{Y}(t)
\end{aligned}
$$

The first two terms in equation $12 \& 13$ are related to shear effects and the third term is indication to turbulent velocity.

According to H.Aoyagi et a (2004)1, the horizontal diffusivity is calculated by the following equation:

$$
\begin{aligned}
& \mathrm{K}^{*}{ }_{\mathrm{x}}(\mathrm{t})=\sum\left(\mathrm{X}^{*}{ }_{\mathrm{i}}(\mathrm{t})^{*} \mathrm{U}^{*}{ }_{\mathrm{i}}(\mathrm{t})\right) /(\mathrm{N}-1) \\
& \mathrm{K}^{*}{ }_{\mathrm{y}}(\mathrm{t})=\sum\left(\mathrm{Y}^{*}{ }_{\mathrm{i}}(\mathrm{t})^{*} \mathrm{~V}^{*}{ }_{\mathrm{i}}(\mathrm{t})\right) /(\mathrm{N}-1)
\end{aligned}
$$

The calculated values by equation $14 \& 15$ form the apparent diffusivity, because it includes both shear and turbulent effects.

\section{RESULTS}

For the calculation of different parameters, the location of the drogue at a certain time is necessary. Each fix was done at a time for one drogue, then it is important to interpolate the position in a fixed time step which is taken as 1 hour.

\section{Track of Drogue:}

The first group of drogue lies in front of Port Said at $15 \mathrm{~m}$ (drogue 3744) and 50m depth (drogue 5533). For the drogue at $15 \mathrm{~m}$ depth the experiment extend from 2 May 1999 till 13 July 1999, this mean that it represents the condition during spring and summer. The track of drogue at $15 \mathrm{~m}$ depth is given in figure (2a). This indicates the existence of a cyclonic gyre covering the area in between $31.68^{\circ}-32.80^{\circ} \mathrm{N}$ and $29.08^{\circ}$ $30.583^{\circ} \mathrm{E}$. Inside this cyclone a small cyclonic eddies can be identified where it take a period in between 7 and 10 days to complete its cycle as shown in figure (2b).

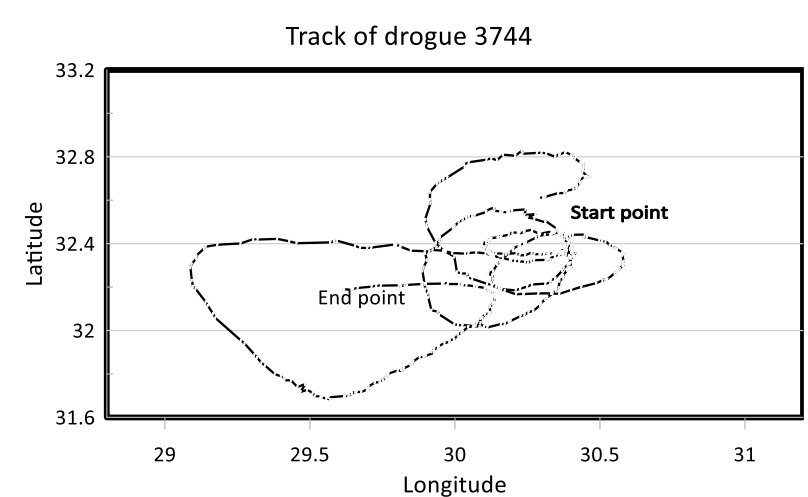

Figure (2-a) track of drogue 3744 at $15 \mathrm{~m}$ depth.

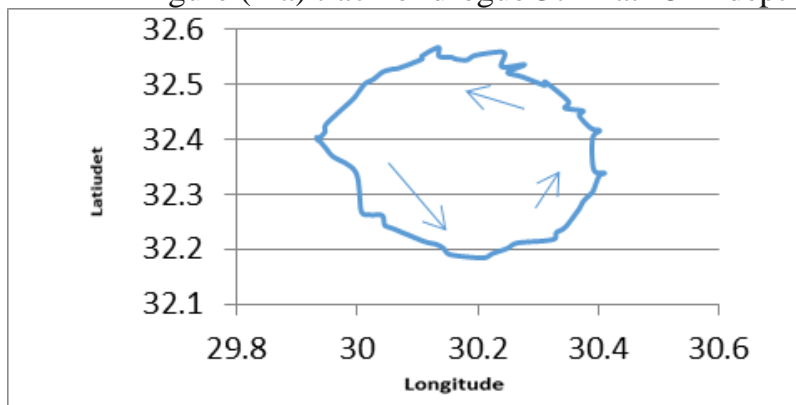

Period from 10May 12:18 to 18May 4:39

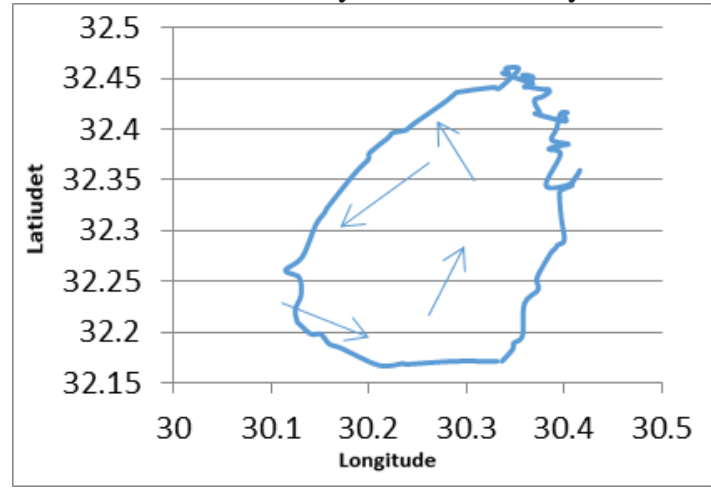

Period from 22May 11:43 to 2June 15:25

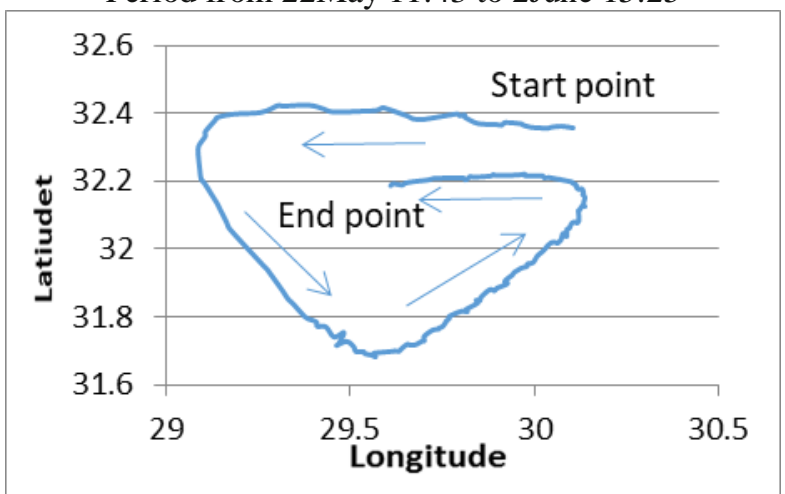

period from 21 June $16: 45$ to 13 July 18:38

Figure (2-b) Track of small eddies

At $50 \mathrm{~m}$ depth the track of the drogues is given in figure (3-a). The experiment extends from 2 May 1999 till 30 June. Also a cyclonic gyre covered the area between $31.882^{\circ}$ - 


\section{International Journal of Engineering Applied Sciences and Technology, 2019 \\ Vol. 4, Issue 7, ISSN No. 2455-2143, Pages 49-57 \\ Published Online November 2019 in IJEAST (http://www.ijeast.com)}

$32.846^{\circ} \mathrm{N}$ and $29.552^{\circ}-30.887^{\circ} \mathrm{E}$. Inside, there is a small cyclonic gyre (fig.3-b). Its cycle extended between 8May 16:16 and 18May 10:48.

The two tracks appear congruence in shape with major axes moving in NE-SW direction. Also, the upper drogue track at $15 \mathrm{~m}$ is extended more to the west considering the period from 2 May to 30June only.

Track of drogue 15533

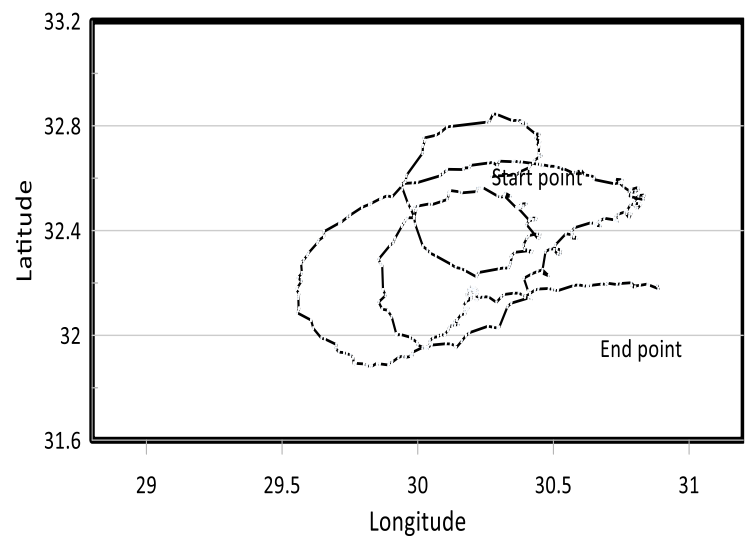

Figure (3-a) Track of drogues 5533 at 50m depth.

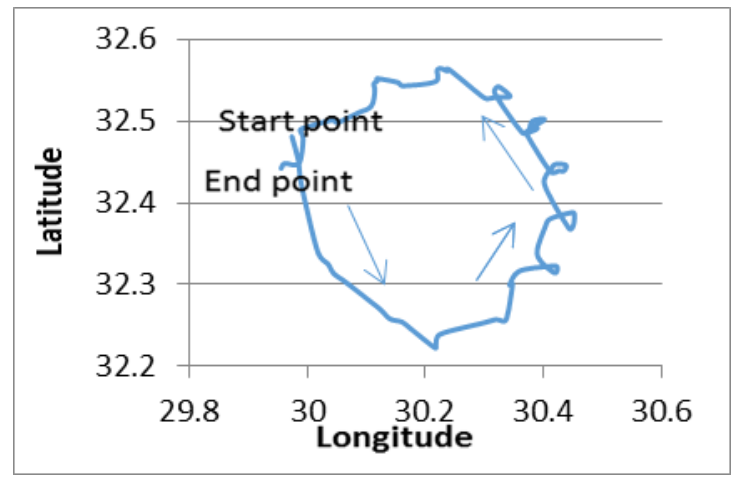

Period from 8May 16:16 to 18 May 10:48

Figure (3-b) The track of small eddy

The second group of drogue lies in front of Rosetta at $15 \mathrm{~m}$ (drogue 1623) and 50m depth (drogue 3745). For the drogue at $15 \mathrm{~m}$ depth, the experiment extends from 4 May to 19 May. The track of drogue at $15 \mathrm{~m}$ depth is given in figure (4). A cyclonic movement appeared to be found in this level.

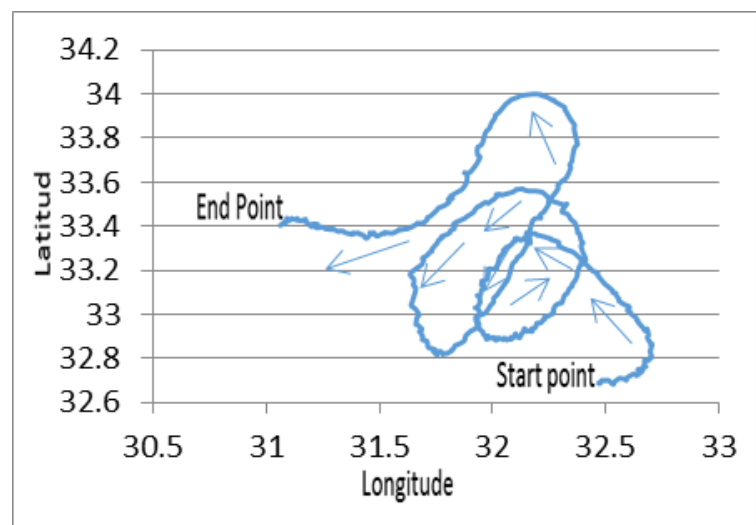

Figure (5-a) Track of drogue 3745

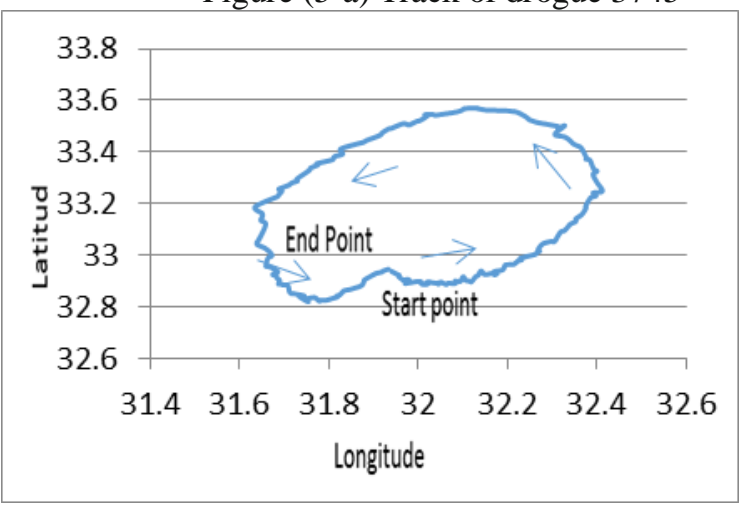

Figure (5-b) Track of one complete gyre

\section{Drogue Velocity:}

The longshore and cross-shore velocities at 15 and $50 \mathrm{~m}$ drogue displacement are calculated using the location of the drogue at a given time. The drogue speed are plotted as a function of time and represented in figure (6\&7) for the two drogues. Both of the cross-shore current and long-shore current are changed its direction from east to west and from north to south respectively. The trend and shape of both longshore and crossshore velocities for the two drogues are similar. Also the mean speed to the south and to the west is higher than that to the north and east direction (table 2).

The same steps are done for drogue 3745 at $50 \mathrm{~m}$. The long-shore and cross-shore speeds are represented in figure (8). The mean speed to the south and to the east is higher than that to the north and west direction (table 3). 


\section{International Journal of Engineering Applied Sciences and Technology, 2019 Vol. 4, Issue 7, ISSN No. 2455-2143, Pages 49-57 \\ Published Online November 2019 in IJEAST (http://www.ijeast.com)}

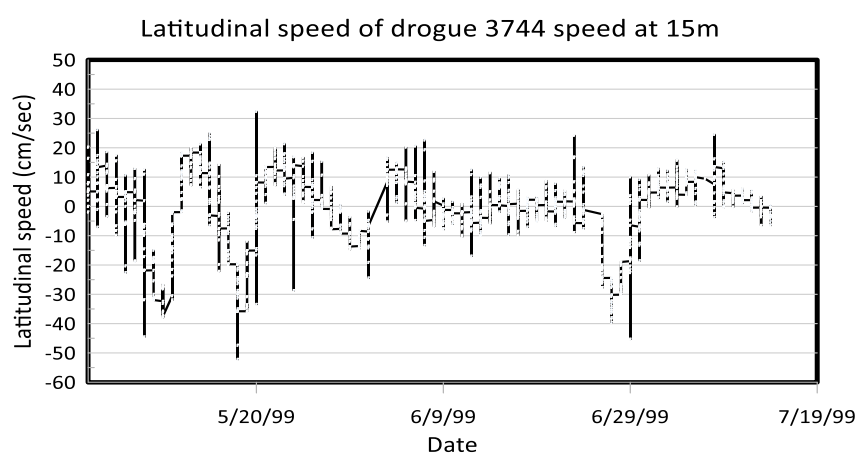

\begin{tabular}{|l|c|c|c|c|c|}
\hline & 11.264 & \pm 11.24 & 10.324 & 12.444 & 12.894 \\
Maximum & 51.212 & 4 & 61.993 & 41.732 & 74.947 \\
Minimum & 0.0004 & 85.997 & 0.052 & 0.009 & 0.724 \\
& & 0.0368 & & & \\
\hline
\end{tabular}

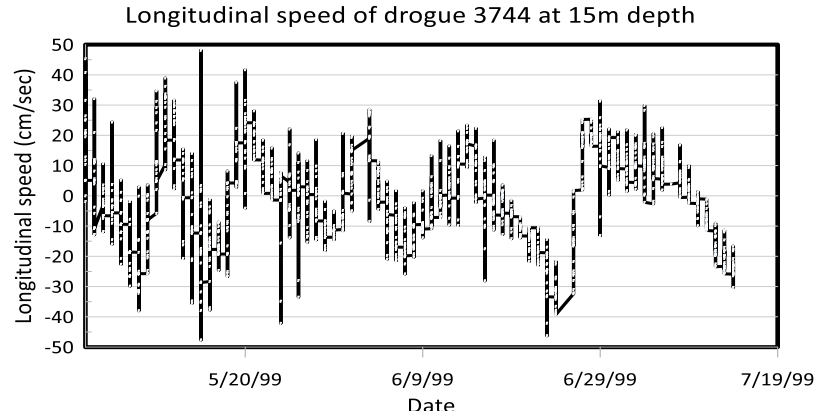

Figure (6) Latitudinal and longitudinal speed inferred from drogue 3744 tracks

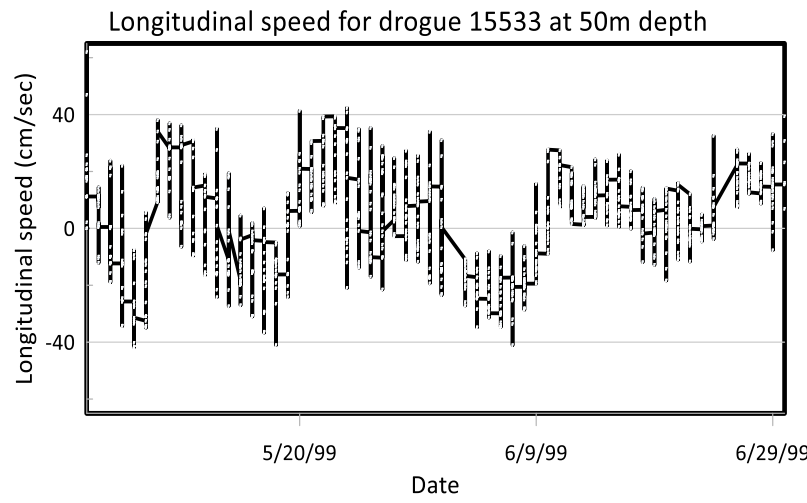

Figure (7) Latitudinal and longitudinal speed inferred from drogue 5533 tracks

Table 2 Mean speed of latitudinal and longitudinal speed

\begin{tabular}{|c|c|c|c|c|c|}
\hline \multirow[t]{2}{*}{$\begin{array}{l}\text { Drogue } \\
\text { velocity }\end{array}$} & \multicolumn{2}{|c|}{$\begin{array}{l}\text { Latitudinal } \\
\text { component }\end{array}$} & \multicolumn{2}{|c|}{$\begin{array}{l}\text { Longitudinal } \\
\text { component }\end{array}$} & \multirow{2}{*}{$\begin{array}{c}\text { Mean } \\
\text { speed } \\
(\mathrm{cm} / \mathrm{sec})\end{array}$} \\
\hline & $\begin{array}{c}\text { East } \\
\text { comp. } \\
(\mathrm{cm} / \mathrm{sec})\end{array}$ & $\begin{array}{c}\text { West } \\
\text { Comp. } \\
(\mathrm{cm} / \mathrm{se} \\
\mathrm{c})\end{array}$ & $\begin{array}{c}\text { North } \\
\text { comp. } \\
(\mathrm{cm} / \mathrm{se} \\
\mathrm{c})\end{array}$ & $\begin{array}{c}\text { South } \\
\text { comp. } \\
(\mathrm{cm} / \mathrm{se} \\
\mathrm{c})\end{array}$ & \\
\hline Drogue 3744 & & & & & \\
\hline Mean speed & $\begin{array}{c}7.203 \pm 5 \\
288\end{array}$ & $\begin{array}{l}10.544 \\
\pm 10.49\end{array}$ & $\begin{array}{l}12.121 \\
\pm 8.738\end{array}$ & $\begin{array}{l}13.232 \\
\pm 8.738\end{array}$ & $\begin{array}{c}17.055 \pm \\
9.944\end{array}$ \\
\hline Maximum & 32.461 & 8 & 48.095 & 47.662 & 48.095 \\
\hline Minimum & 0.014 & $\begin{array}{l}52.176 \\
0.0177\end{array}$ & $\begin{array}{c}0.0033 \\
7\end{array}$ & 0.0069 & -47.662 \\
\hline Drogue 5533 & & & & & \\
\hline Mean speed & $14.855 \pm$ & 19.983 & $13.20 \pm$ & $14.92 \pm$ & $24.571 \pm$ \\
\hline
\end{tabular}
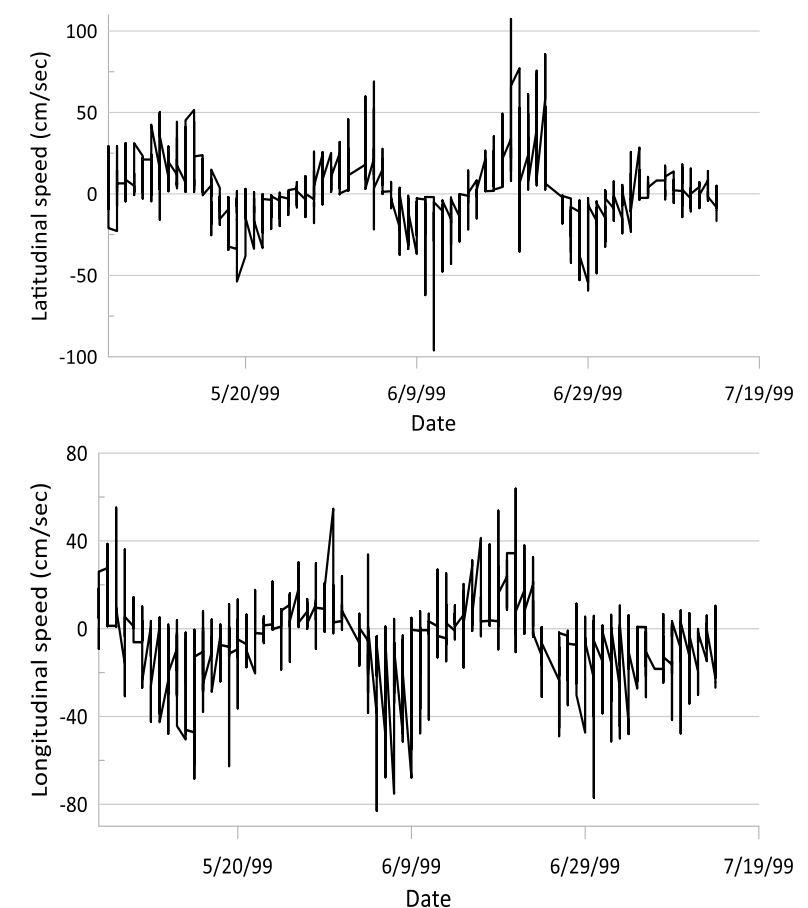

Figure (8) Latitudinal and longitudinal speed inferred from drogue 3745 tracks

Table (3) Mean speed of latitudinal and longitudinal speed

\begin{tabular}{|l|c|c|c|c|c|}
\hline \multirow{2}{*}{$\begin{array}{l}\text { Drogue } \\
\text { velocity }\end{array}$} & \multicolumn{2}{|l|}{$\begin{array}{l}\text { Latitudinal } \\
\text { component }\end{array}$} & \multicolumn{2}{l|}{$\begin{array}{l}\text { Longitudinal } \\
\text { component }\end{array}$} & \begin{tabular}{c} 
Mean \\
speed \\
\cline { 2 - 5 }
\end{tabular} \\
\cline { 2 - 5 } & $\begin{array}{c}\text { East } \\
\text { comp. } \\
(\mathrm{cm} / \mathrm{sec})\end{array}$ & $\begin{array}{c}\text { West } \\
\text { Comp. } \\
(\mathrm{cm} / \mathrm{sec})\end{array}$ & $\begin{array}{c}\text { North } \\
\text { comp. } \\
(\mathrm{cm} / \mathrm{sec})\end{array}$ & $\begin{array}{c}\text { South } \\
\text { comp. } \\
(\mathrm{cm} / \mathrm{sec})\end{array}$ & \\
\hline$\underline{\text { Drogue }}$ & & & $7.165 \pm$ & $10.87 \pm$ & $-2.28 \pm$ \\
$\underline{\mathbf{3 7 4 5}}$ & $10.32 \pm$ & $8.154 \pm$ & & & 12.77 \\
Mean & 13.29 & 10.197 & 8.086 & 12.09 \\
speed & 107.42 & 95.993 & 63.792 & 82.94 & 63.79 \\
Maximum & $1.55 \mathrm{E}-5$ & 0.00025 & 0.0431 & 0.0107 & -77.01 \\
Minimum & & & & & \\
\hline
\end{tabular}

\section{Dispersion and diffusion:}

The centroid of a set of drogue is calculated using equation $1 \& 2$. Then the relative mean square displacement of the drogue is calculated using equation $3,4 \& 5$. The relative dispersion coefficient is calculated using equation $6,7 \& 8$. The obtained results are represented in figures $(9,10 \& 11)$ for drogue 3744,5533 and drogue 3745 respectively.

The mean values of relative dispersion $\mathrm{k}_{\mathrm{x}}$ and $\mathrm{k}_{\mathrm{y}}$ are given in table (4). These values of $\mathrm{k}_{\mathrm{x}}$ and $\mathrm{k}_{\mathrm{y}}$ represent open 


\section{International Journal of Engineering Applied Sciences and Technology, 2019 \\ Vol. 4, Issue 7, ISSN No. 2455-2143, Pages 49-57 \\ Published Online November 2019 in IJEAST (http://www.ijeast.com)}

ocean condition as stated by Rengarajan et al (2002). Also the value in shallower level $(15 \mathrm{~m})$ in front of Port Said is less than that in deep level $(50 \mathrm{~m})$ vice versa that in front of Rosetta.

Table (4) The mean values of relative dispersion

\begin{tabular}{|l|l|l|}
\hline Drogue number & $\mathrm{K}_{\mathrm{x}}\left(\mathrm{cm}^{2} / \mathrm{sec}\right)$ & $\mathrm{K}_{\mathrm{y}}\left(\mathrm{cm}^{2} / \mathrm{sec}\right)$ \\
\hline 3744 & $3.78 \times 10^{5}$ & $8.18 \times 10^{5}$ \\
\hline 5533 & $4.93 \times 10^{6}$ & $2.12 \times 10^{4}$ \\
\hline 1623 & $9.93 \times 10^{6}$ & 0.274 \\
\hline 3745 & $6.11 \times 10^{6}$ & $2.49 \times 10^{6}$ \\
\hline
\end{tabular}

Both of $\mathrm{K}_{\mathrm{x}}$ and $\mathrm{K}_{\mathrm{y}}$ are oscillated. The negative values occurred when the drogue move to the west or to the south. Also, the $\mathrm{K}$ values are oscillating as that of $\mathrm{K}_{\mathrm{x}}$ and $\mathrm{K}_{\mathrm{y}}$ but with different period of oscillation.

$\mathrm{Kx}(\mathrm{t})$ of drogue 3744 at $15 \mathrm{~m}$ depth

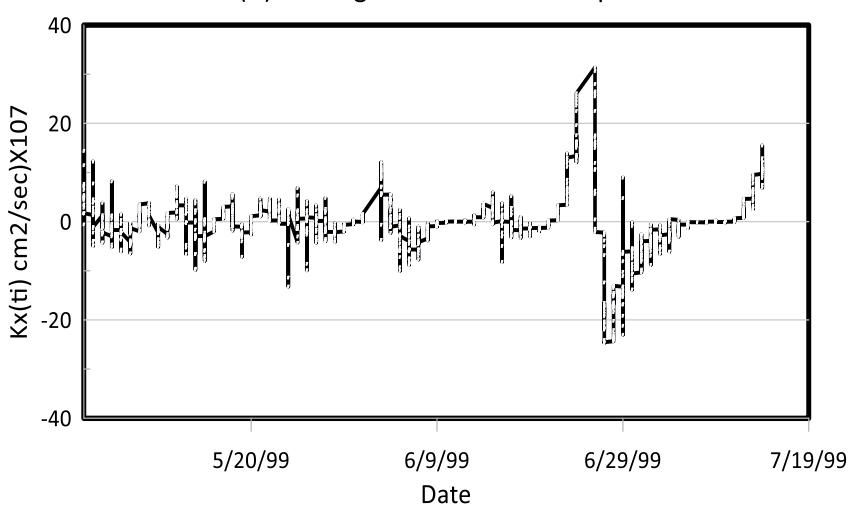

$\mathrm{Ky}(\mathrm{ti})$ for drogue 3744 at $15 \mathrm{~m}$

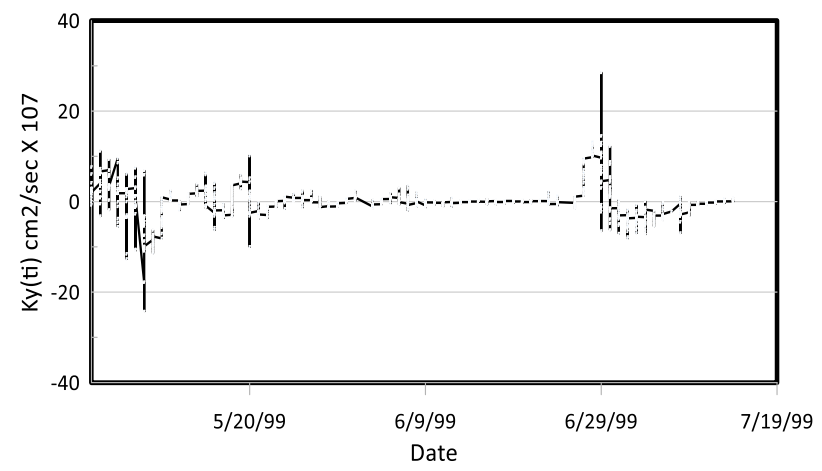

$\mathrm{Kt}(\mathrm{i})$ of drogue 3744 at $15 \mathrm{~m}$

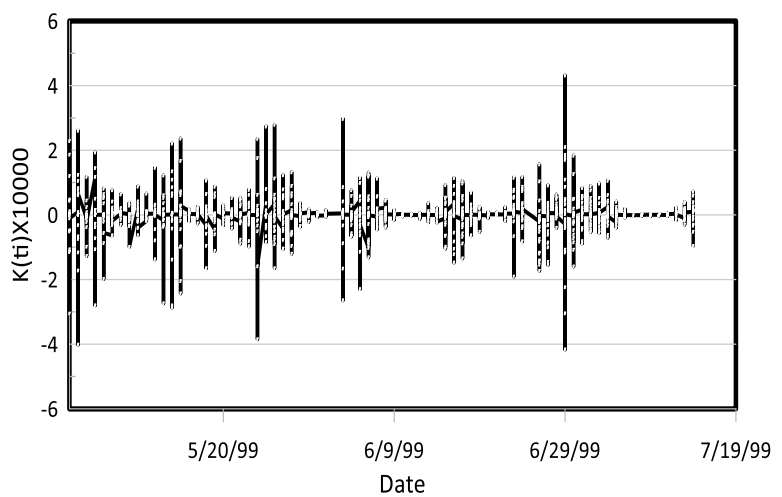

Figure 9 Relative Dispersion coefficients $\left(\mathrm{cm}^{2} / \mathrm{sec}\right)$ from $15 \mathrm{~m}$ depth

Kx(ti) for drogue 15533 at $50 \mathrm{~m}$

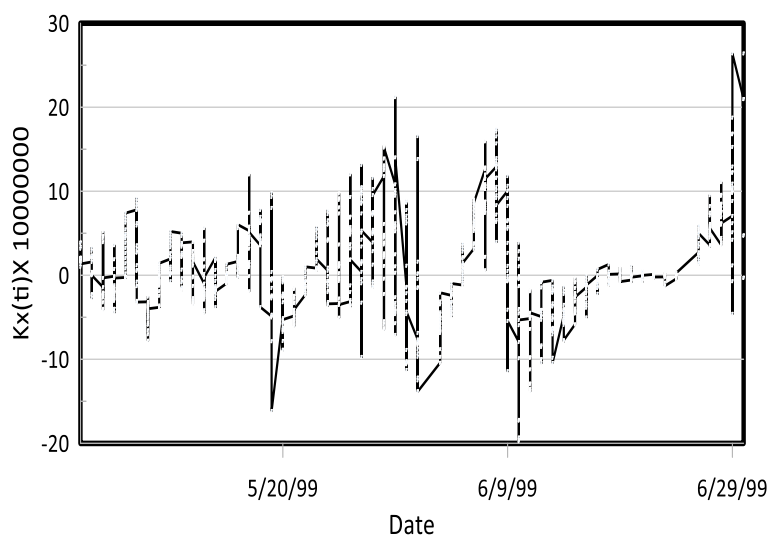

Ky(ti) for drogue 15533 at $50 \mathrm{~m}$

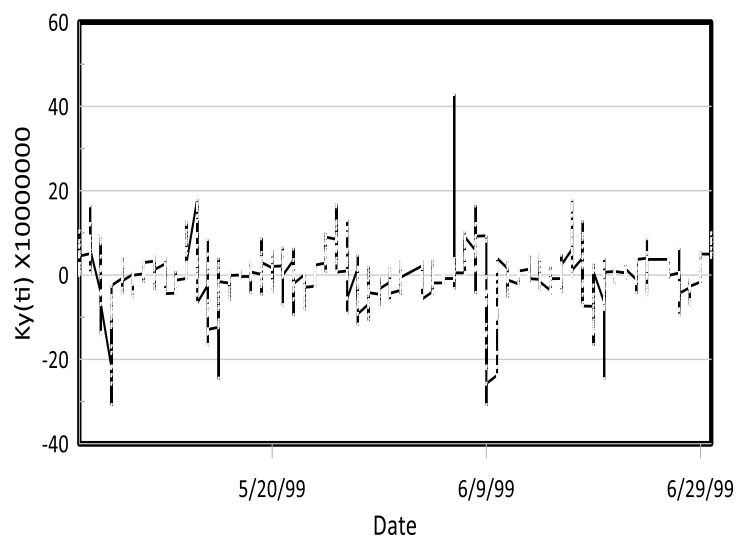

$\mathrm{K}(\mathrm{ti})$ for drogue 15533 at $50 \mathrm{~m}$

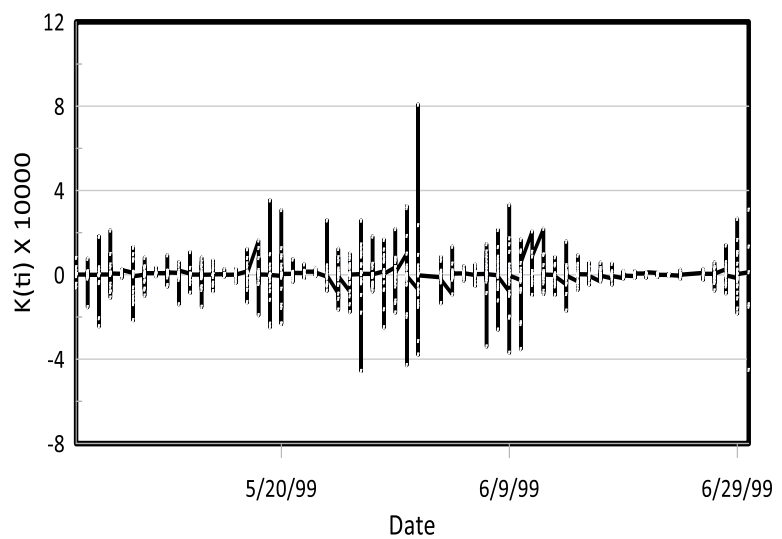

Figure 10. Relative Dispersion coefficients $\left(\mathrm{cm}^{2} / \mathrm{sec}\right)$ from $50 \mathrm{~m}$ depth 
International Journal of Engineering Applied Sciences and Technology, 2019

Vol. 4, Issue 7, ISSN No. 2455-2143, Pages 49-57

Published Online November 2019 in IJEAST (http://www.ijeast.com)
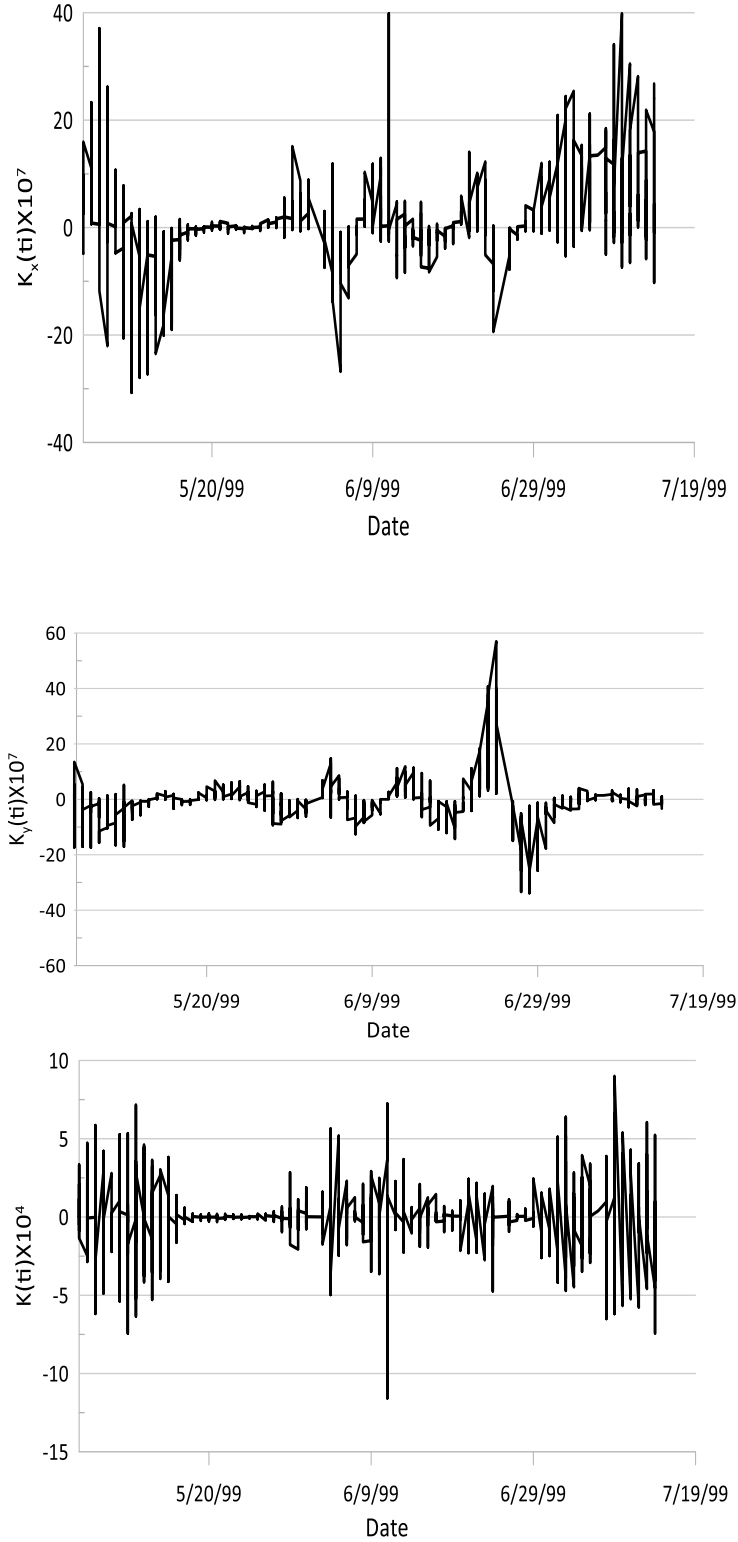

Figure 11. Relative Dispersion coefficients $\left(\mathrm{cm}^{2} / \mathrm{sec}\right)$ from $50 \mathrm{~m}$ depth

\section{Horizontal Divergence:}

The Values of horizontal divergence (Q) for drogue 3744, 5533 and 3745 , are represented in figure $(12,13 \& 14)$. It is clear that the horizontal movement is fluctuated between convergence $(\mathrm{Q}$ is negative) and divergence ( $Q$ is positive) at the two levels.

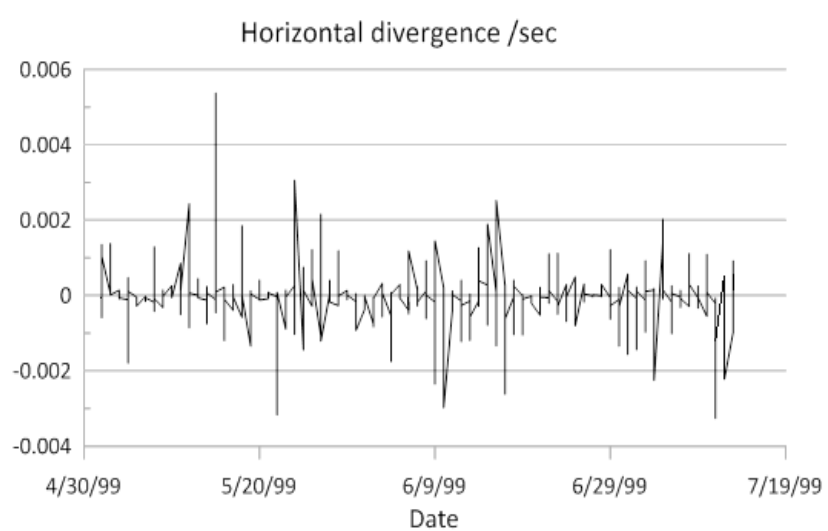

Figure (12) Horizontal divergence (Q) of drogue

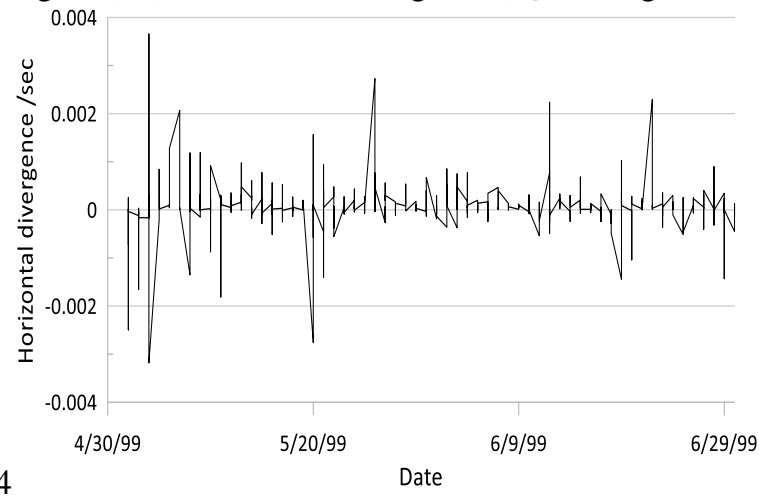

Figure (13) Horizontal divergence (Q) of drogue 5533

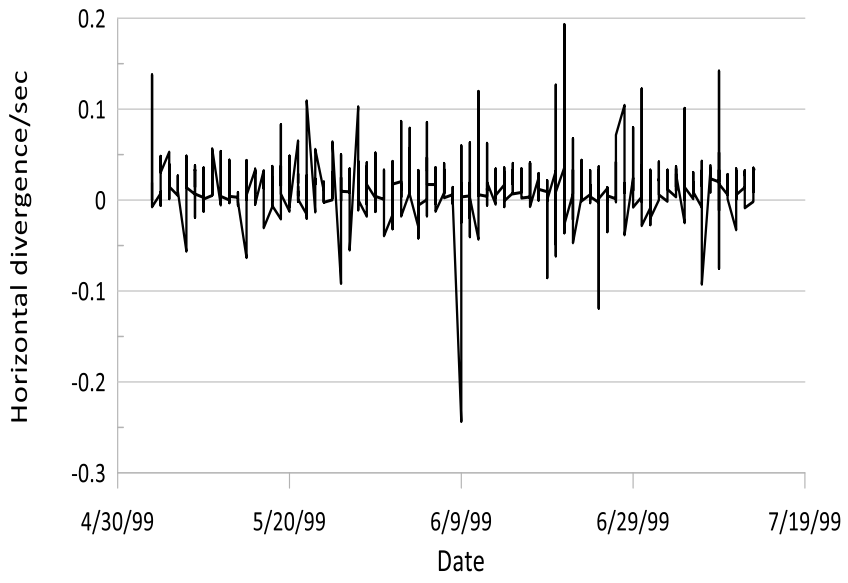

Figure (14) Horizontal divergence (Q) of drogue 3745

\section{Horizontal Diffusivity:}

The horizontal diffusivity calculation by equation $10,11,12$ \&13 includes both shear and turbulence effects. The shear effects are represented in figure $(15,16$ \&17) for drogues 3744 , 5533 and 3745 respectively. Also the turbulent effects for the drogues are represented in figure $(18,19 \& 20)$. 


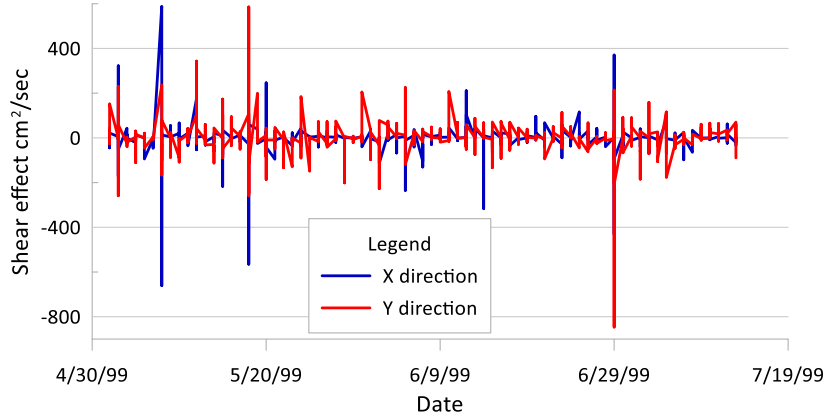

Figure (15) Shear effects in X and Y direction in drogue 3744

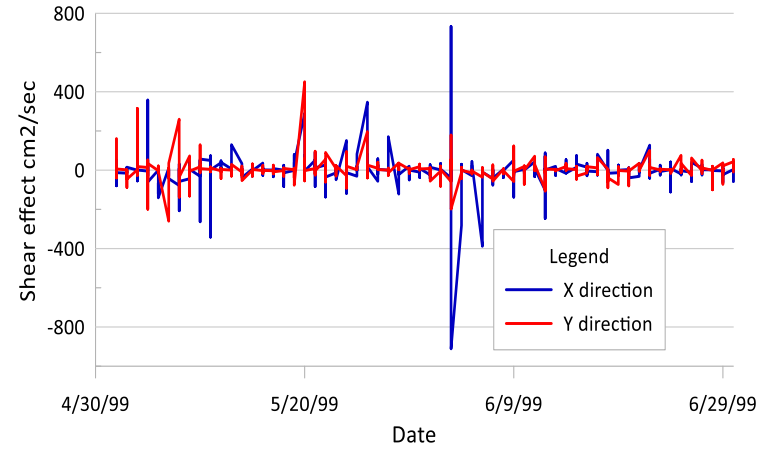

Figure (16) Shear effects in X and Y direction for drogue 5533

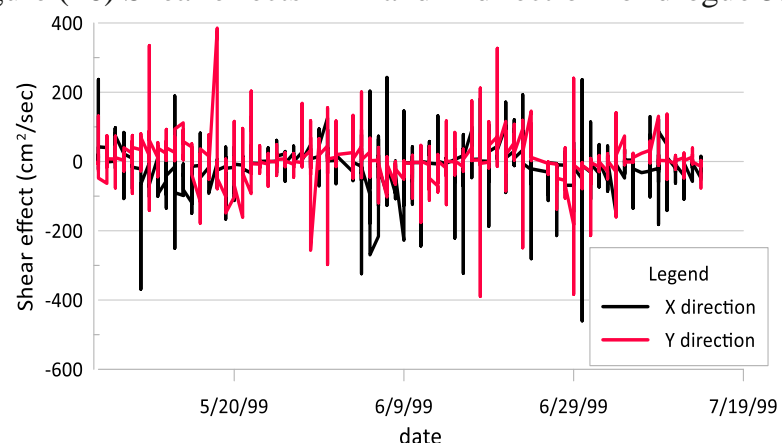

Figure (17) Shear effects in X and Y direction for drogue 3745

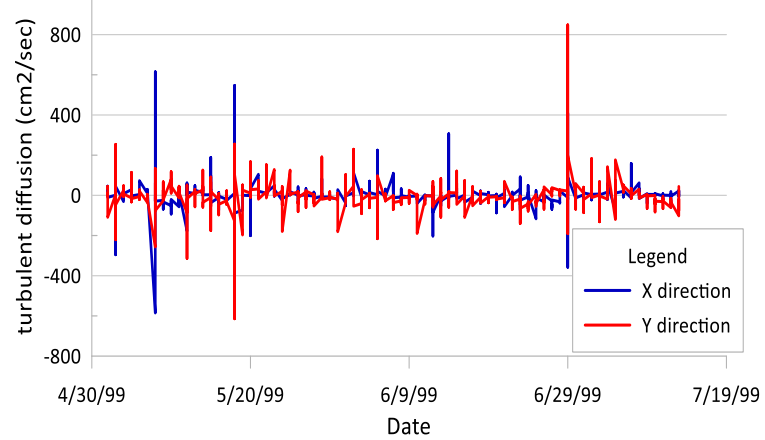

Figure (18) Turbulent effect in X\&Y direction for drogue 3744

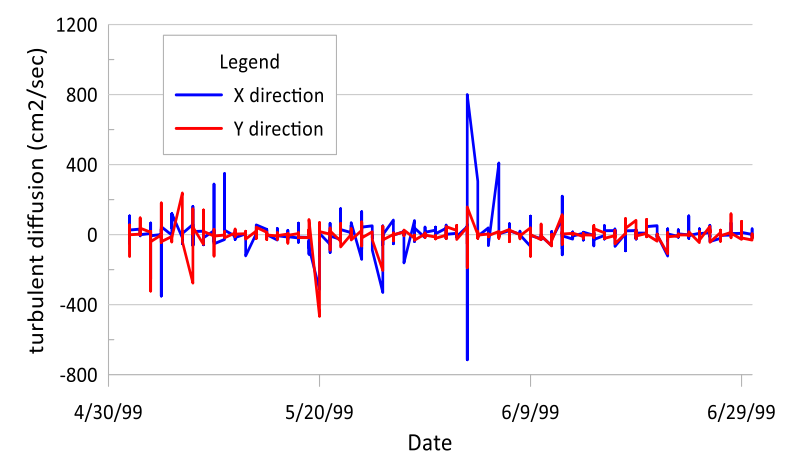

Figure (19) Turbulent effect in X\&Y direction for drogue 5533

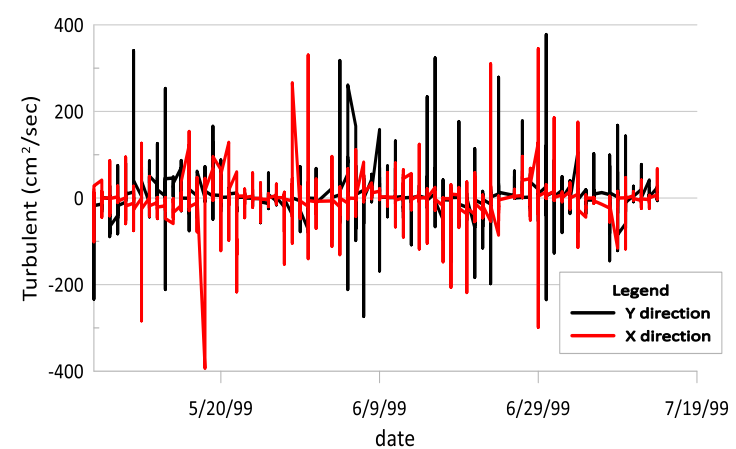

Figure (20) Turbulent effect in X\&Y direction for drogue 3745

Generally, the change in pattern in both relative dispersion (fig. 9,10\&11) and divergence (fig. 12,13\&14) is approximately the same which indicate that the shear effect is high. The turbulent diffusivity is smaller than apparent diffusivity which means that the effect of turbulence is relatively small.

Sometimes the turbulent diffusivity is negative which is consistent with diffusion parameters.

\section{CONCLUSION}

A statistical analysis of drifter at 15 and $50 \mathrm{~m}$ in front of Nile Delta is used to estimate track, latitudinal and longitudinal velocity and eddy diffusivity in the investigated area.

The track of the all drogues appears the existence of cyclonic motion covering the investigated area.

The alongshore and cross shore velocity are oscillating from north to south and from east to west. The south and west component are higher than that of north and east components.

The relative dispersion coefficient values are in the order of $10^{6} \mathrm{~cm}^{2} / \mathrm{sec}$ in the two areas.

The horizontal divergence is oscillating between convergence and divergence.

The effect of turbulence is relatively small in comparison with apparent diffusivity.

\section{REFERENCE}




\section{International Journal of Engineering Applied Sciences and Technology, 2019 \\ Vol. 4, Issue 7, ISSN No. 2455-2143, Pages 49-57 \\ Published Online November 2019 in IJEAST (http://www.ijeast.com)}

Castanedo S, Medina R, Losada IJ, Vidal C, Méndez FJ, Osorio A, Juanes JA, Puente A. (2006). The Prestige oil spill in Cantabria (Bay of Biscay). Part I: operational forecasting system for quick response, risk assessment, and protection of natural resources. J Coast Res 22(6):1474-1489

Coppini G., De-Dominicis M., Zodiatis G., Lardner R., Pinardi N., Santoleri R., Colella S. et al (2010). Hindcast of oil spill pollution during the Lebanon Crisis, July-August 2006. Mar Pollut Bull 62:140-153

De-Dominicis I , Giovanni L., Paolo M., Nadia $\mathbf{P}$ and Pierre-Marie P.' (2012). Eddy diffusivity derived from drifter data for dispersion model applications. Ocean Dynamics, 62:1381-1398.

Erik van Sebille,a,b, Stephen M.G., Abernatheyd R., Thomas P. A., Pavel B., Arne B., Bruno B., Eric P. C., Chengj Y., Colin J. C., Eric D., Kristofer D., Henri F. D.,p, Sybren D., Stefan F. G., Arnold W. H., Joakim K., Inga M. K., Michael L., Camille L., Graeme A. M., Robert M., Gabriela M. A., Aoyagi H., Michida Y., Inada M., Otobe H. and Takimoto R. (2004). Experiment of particle dispersion on the sea surface with GPS tracked drifters. Ocean'04MTS/IEEE Techno-Ocean' (IEEE car. Nao4CH337600. Conference Kobe, Japan J. Arch.

Foxworthy J.E., Tibby R.B., and Barsom GM. (1966). Dispersion of a surface

waste field in the sea," Jounal of Water Pollutants Control Federation, Vol. 38, NO. 7 : 1170-1193.

Ivanov L.M. and Chu P.C. (2019)'. Estimation of turbulent diffusion coefficients from decomposition of Lagrangian trajectories. Ocean Modelling, vol. 137, pp:114-131

List E.J., Fellow A., Gregory G., ASCE M. and Clintion D. W. (1990). Diffusion and dispersion in coastal waters. Journal of Hydraulic engineering, vol. 116 No. 10:1158-1179.

List SI. E.J., Gartrell G., and Winant C.D., (1990). Diffusion and dispersion in coastal waters," Jounal of Hydraulic Engineering, Vol. 116, No. 10, : 1158-1179.

Morcos S.A., Hasan S.H. (1976). The water masses and circulation in the south eastern Mediterranean J. Acta Adriatica, 18 (12) :195-218.

Okubo A., (1971). "Oceanic diffusion diagrams," Deep Sea Research, Vol. 18: ( pp. 789-802).

Rengarajan R.; Sahu, M.M.; Somayajulu B.L.K. and Suhasini, R. (2002)'. Mixing in the surface waters of Western Bay of Bengal using $228 \mathrm{Ra}$ and 226 Ra. J. Mar.Res., 60:255279.

Ronan Mc., Francesco N., Claire B. P., Matthew D. P., Jeff A. P., Siren R., Syed H.A.M., Matthew D. T., Jinbo W., Phillip J. W., Laure Z., and Jan D. Z., (2018). Lagrangian ocean analysis: Fundamentals and practices. Ocean Modelling vol. 121: 49-75.

Said M.A., Eid F.M. (1995). Circulation pattern of the Egyptian Mediterranean waters during winter and summer seasons Pak. J. Mar. Sci., 3 (2) : 91-100
Said M.A., El-Gindy A., and Radwan A.A. (2013). Surface circulation of the Egyptian Mediterranean waters using satellite tracked Lagrangian rifters JKAU: Mar. Sci., 24 (1) : 68-81

Said M.A., Karam A.M. (1990). On the formation of intermediate water masses off the Egyptian mediterranean coast. Hydrobiol., 120 (1) :111-122

Said M.A.and Eid F.M. (1994). Circulation pattern of the Egyptian Mediterranean Waters during winter and summer seasons. Pakistan Journal of Marine Sciences, Vo1.3(2): 91100 .

Sharaf El-Din S.H., Karam A.M. (1973). Geostrophic currents in the south eastern sector Mediterranean Sea J. Acta Adriatica, 18 (13) : 221-235

Victor Z., Dmitry L., and Natalia K. (2014). Drifter-derived estimates of lateral eddy diffusivity in the World Ocean with emphasis on the Indian Ocean and problems of parameterization. Deep sea research vol $183: 1-11$.

Yanagi T., Murashita K., and Higuchi H. (1982). "Horizontal turbulent diffusivity in the sea," Deep Sea Research, Vol. 29, NO. 2A, : 217-226.

Yoshitaka M., Isamu F. (2014). Horizontal turbulent diffusion at sea surface for oil transport simulation. Coastal Engineering. :1-10.

Yuqi S. (2017). Estimating longitudinal dispersion coefficients in in natural channels. M.Sc. Thesis, IOWA State University, $51 \mathrm{pp}$. 